\title{
Evaluating Woody Ornamentals for Use in Herbicide Phytoremediation
}

\author{
Martin Baz ${ }^{1}$ and R. Thomas Fernandez ${ }^{2}$ \\ Department of Horticulture, Michigan State University, East Lansing, MI 48824-1325
}

\begin{abstract}
ADDITIONAL INDEX WORDS. chlorophyll fluorescence, $\mathrm{CO}_{2}$ assimilation, gas exchange, herbicide tolerance, isoxaben, photosynthesis, oryzalin

Aвstract. Itea virginica L. 'Sprich' (virginia sweetspire), Salix alba L. (white willow), and S. gracilistyla var. melanostachys (Mak.) Miq. (black pussywillow) were treated with a $4 \mathrm{mg} \cdot \mathrm{L}^{-1}$ suspension of two herbicides, isoxaben and oryzalin, a water control (water) or a nonsaturated control (control) for 9 days. Growth and photosynthetic responses were monitored before, during and after the 9-day treatment for a total of 51 days. Growth index of white willow and virginia sweetspire was only reduced by isoxaben treatment while both herbicides reduced the growth index for black pussywillow compared to control. Plant dry weights of the willows were not affected by day 9 . Final dry weight was lower for both herbicide treatments for all taxa. The water treatment resulted in lower total dry weight than control only for virginia sweetspire. Isoxaben reduced photosystem II efficiency $(\mathrm{Fv} / \mathrm{Fm})$ and $\mathrm{CO}_{2}$ assimilation (A) following release from treatments of virginia sweetspire and black pussywillow. There were few differences in Fv/Fm and A for white willow. The response to oryzalin was similar to water for most parameters measured for virginia sweetspire and white willow. Growth was more strongly affected by oryzalin for black pussywillow than for other taxa but there were few differences in $\mathrm{Fv} / \mathrm{Fm}$ or A between oryzalin and control for any of the taxa. Virginia sweetspire and white willow showed promise for use in phytoremediation of oryzalin but none of the taxa performed well under the levels of isoxaben used. Chemical names used: isoxaben $(N$-[3-(1-ethyl-1-methylpropyl)-5-isoxazolyly]-2,6-dimethoxybenzamide); oryzalin (4-(dipropylamino)-3,5dinitrobenzenesulforamide).
\end{abstract}

Preemergent herbicides are frequently used in container nursery production to manage weeds. During the growing season, herbicides are often applied at 70- to 90-d intervals. During application, up to $80 \%$ of applied pesticides can miss the intended target and fall directly onto the production surface (Gilliam et al., 1992). Daily irrigation is typical for container nurseries during the peak growing season. Overhead irrigation is the most common type of irrigation used for container nurseries and the same percentage of water can miss the target as pesticides. The combination of pesticides on the production surface and large quantities of water being applied can result in substantial runoff and transport of herbicides to containment basins and/or offsite.

Detectable levels of pendimethalin ( $N$-(1-ethylpropyl)-3,4dimethyl-2,6-dinitrobenzenamine), oxyfluorfen (2-chloro-1-(3ethoxy-4-nitrophenoxy)-4-(trifluoromethyl) benzene) and oryzalin were found in water and sediments of containment basins at container nurseries (Camper et al., 1994; Riley et al., 1994). Isoxaben was also detected in nursery runoff water (Wilson et al., 1996). In a runoff study conducted at an ornamental container nursery, Keese et al. (1994) found oryzalin residues of $4 \mathrm{mg} \cdot \mathrm{L}^{-1} 15$ minutes after runoff began on the day of application. In another study, isoxaben residues were found at $3.26 \mathrm{mg} \cdot \mathrm{L}^{-1}$ within the first 20 minutes of runoff on the day of application (Briggs, 1996). While trace amounts of herbicides can be beneficial for controlling sensitive weeds (Skimina, 1992), phytotoxicity can result when sensitive nursery crops are irrigated with recycled water containing herbicide residues or when one herbi-

Received for publication 21 Dec. 2001. Accepted for publication 23 July 2002. Support for this research was provided by Project GREEEN of the Michigan Agricultural Experiment Station. We thank the U.S. Department of Energy, the National Science Foundation, Michigan State University, and the Auxein Corporation for funding the Undergraduate Researchers In Plant Sciences Program and Dan Kort for his assistance on the project.

${ }^{1}$ Participant in the MSU Undergraduate Researchers in Plant Sciences Program from Universidad de la República, Montevideo, Uruguay.

${ }^{2}$ Assistant professor, corresponding author; e-mail fernan15@msu.edu. cide is used extensively (Bhandary et al., 1997a; Skimina, 1992). Oryzalin, oxyfluorfen and isoxaben caused reduced growth of daylily (Hemerocallis $\times$ L.) and fountain grass (Pennisetum rupelli Steudel) at concentrations of 1 and $10 \mathrm{mg} \cdot \mathrm{L}^{-1}$ and root damage to holly (Ilex crenata Thunb.) at $10 \mathrm{mg} \cdot \mathrm{L}^{-1}$ (Bhandary et al., 1997a). Runoff water and associated contaminants from nurseries that do not recycle irrigation water may contaminate surface or ground water. The contamination of water resources by nonpoint source pollution and the detrimental reintroduction of pollutants onto the crop through recycling necessitates the use of techniques to reduce movement and enhance remediation of agricultural chemicals in runoff waters.

Grasses and semiaquatic plants have been used effectively to remove nutrients and sediments from runoff water (Dillaha et al., 1989; Thut, 1990; Wolverton et al., 1983). Vegetative filter strips (VFS) are used extensively in treatment of municipal waste waters and runoff waters from pulp mills and livestock feed lots. A VFS is a vegetated area which receives and purifies runoff from an up-slope pollutant source (Chaubey et al., 1994). Vegetative filter strips cause a reduction in water flow and allow time for plant uptake or infiltration of pollutants into soils and subsequent degradation resulting in reduced transport capacity and sediment movement of runoff waters. Effectiveness of a VFS is based on the flow depth and velocity of the runoff water, vegetation density, incoming sediment and pollutant loads, and size and slope of the VFS (Dillaha et al., 1989). Vegetative filter strips are a low cost, estimated at $\$ 93 / \mathrm{t}$ of abated sediment, and practical option for improving the quality of runoff water (Pritchard et al., 1993). Vegetative filter strips have reduced herbicide and fungicide concentrations in nursery runoff water (Briggs et al., 1998).

Nonpoint source pollution is becoming a major concern for the nursery industry. The industry must find an effective and economical method for water decontamination. One economical option for removing pollutants from runoff is phytoremediation (Pritchard et al., 1993; Shimp et al., 1993). Although VFS have been used to filter herbicides and other contaminants effectively, 
land that is used for remediation is lost to production. Aquatic plants in a nursery environment have been evaluated for use in mitigating nutrient levels from catfish production ponds (Bilderback et al., 1993). A similar technique is envisioned for remediation of runoff water from nursery beds, where runoff is channeled through retention areas with container-grown, semiaquatic plants for remediation of nutrients and pesticides as well as production of these plants for future sale. Use of a remediation area for crop production could be profitable and effective in removing contaminants. Some ornamental herbaceous perennials showed some tolerance to high levels of herbicides likely to be encountered in phytoremediation areas (Fernandez et al., 1999), however, response of woody ornamental species to such conditions has not been determined. Therefore, the objectives of this study were to determine the response of three woody ornamental plants to two commonly used herbicides, isoxaben and oryzalin, at levels likely to be encountered in such a phytoremediation area.

Isoxaben and oryzalin are classified by the EPA as Group C possible human carcinogens (Anonymous, 1993, 2001a). Toxicity of isoxaben to aquatic organisms is considered low (Anonymous, 2000). The half-life of isoxaben in water ranged from 3.9 $\mathrm{d}$ in summer to $65.3 \mathrm{~d}$ in winter (Anon., 1996). Oryzalin is highly toxic to aquatic organisms with an $\mathrm{LC}_{50}$ or $\mathrm{EC}_{50}$ value between 0.1 and $1 \mathrm{mg} \cdot \mathrm{L}^{-1}$ for the most sensitive species (Anonymous, 1995, 2002). No hydrolysis of oryzalin was found in water at $\mathrm{pH} \mathrm{5,} \mathrm{7,}$ and 9 (Anonymous, 1995). Isoxaben and oryzalin are considered potential groundwater contaminants in California (Anonymous, 2001b). Oryzalin is not strongly bound to soil particles and is slightly soluble in water, although it does bind to organic matter (Anonymous, 1996). In situations with low organic matter content, high rainfall or irrigation, and shallow water tables, oryzalin can present a risk of groundwater contamination (Anonymous, 1996). Potential groundwater contamination from isoxaben is relatively low since it has a $\mathrm{K}_{\mathrm{oc}}$ of 1400 , is moderately adsorbed to soil particles, and is not easily leached (Anonymous, 1987). Oryzalin and isoxaben have been found in container nursery runoff water following application of the herbicides and have the potential to contaminate surface water (Briggs, 1996; Keese et al., 1994; Wilson et al., 1996).

\section{Materials and Methods}

This research was conducted in a polyethylene greenhouse at the Horticulture Teaching and Research Center, Michigan State University, East Lansing. Plant response to two common preemergent herbicides, isoxaben (Gallery 75DF) and oryzalin (Surflan 4AS) (Dow AgroSciences, Indianapolis, Ind.), were evaluated. Both of these preemergent herbicides are used commonly in nursery production (Neal and Senesac, 1990; Skroch et al., 1994). Three plants of ornamental commercial value that are reportedly tolerant of saturated soil conditions, black pussywillow, white willow, and virginia sweetspire, were evaluated as potential phytoremediation candidates. Rooted cuttings received from a commercial propagation nursery were potted in standard no. 1 nursery containers (3.8 L volume) in a 3 pine bark fines : 1 sphagnum peat : 1 composted rice hull substrate on 8 Apr. and 13 June 2000 for virginia sweetspire and the two willows, respectively. All plants were fertilized with a soluble $200 \mathrm{mg} \cdot \mathrm{L}^{-1} 20 \mathrm{~N}$ 1.7P-9.2K fertilizer immediately after transplanting and on 3 July.

To determine plant response to the highest expected exposure levels based on previous studies (Briggs, 1996; Keese et al.,
1994), containers were placed in 4.75-L plastic buckets (Leaktite, Leominster, Mass.) to create a treatment reservoir. Treatments applied in the buckets were $1 \mathrm{~L}$ of a $4 \mathrm{mg} \cdot \mathrm{L}^{-1}$ suspension of isoxaben or oryzalin, water, or a well-watered (daily irrigation to runoff) but not saturated control. Treatments were imposed 18 to 27 July (day 0 to 9) 2000. There were 14 replications per treatment of each willow and eight replications of virginia sweetspire. The plants were arranged in a completely randomized design. Treatment suspensions or water were applied to the reservoir buckets every second day over $9 \mathrm{~d}$ for a total of five treatments. Since herbicides can degrade or be taken up and metabolized by plants, treatments were replaced every other day to maintain a high concentration. Opaque blue buckets were use to decrease herbicide photodegradation. The height of the buckets was equal to the height of the containers. Plants were grown in this system beginning 11 July 2000 until implementation of the treatments. During this time water was supplied to maintain about a $4-\mathrm{cm}$ water reservoir in the buckets so that plants would acclimate to saturated water conditions. After termination of treatments, all plants were watered as they were the week before imposition of treatments. Control plants were not grown in the buckets and were watered daily to runoff from the drainage holes of the containers throughout the duration of the experiment.

Plant performance during treatments and recovery from treatments was determined by measuring growth, leaf gas exchange and chlorophyll fluorescence. Leaf $\mathrm{CO}_{2}$ assimilation (A), transpiration and stomatal conductance were measured every 2 to $3 \mathrm{~d}$ during the treatment period and approximately twice weekly during recovery as weather permitted using a portable infrared gas analyzer (CIRAS-1; PP Systems, Haverhill, Mass.) with a broadleaf chamber (CIRAS-1 Parkinson leaf cuvette, PP Systems, Haverhill, Mass.). One recently mature, fully expanded leaf per plant was measured beginning at $\approx 1100 \mathrm{~h}$. Photosynthetically active radiation $(P A R)$ and air temperature were measured at the same time as leaf gas exchange with a silica quantum sensor and precision thermistor attached to the leaf cuvette. Dark adapted chlorophyll fluorescence was measured on the same type of leaf using a continuous excitation fluorometer (plant efficiency analyzer, Hansatech Instruments, LTD, King's Lynn, Norfolk, U.K.) on leaves that had been dark acclimated for a minimum of $10 \mathrm{~min}$. Plant height and width were measured $9 \mathrm{~d}$ before initial treatment, at initiation of treatment (day 0 ) immediately following termination of treatment (day 9) and on day 43. Growth index (GI) was calculated as (plant height + width)/2. Six replications of both willows were harvested on day 9 and separated into roots, leaves and shoots for dry weight determination. The remaining eight replicates of all plants were harvested at termination of the experiment on 31 Aug. 2000 (day 44) and separated into roots and shoots for dry weight determination.

Data were subjected to analysis of variance using the PROC GLM procedure of SAS (SAS Inst., Inc., Cary, N.C). Mean separation for leaf gas exchange, chlorophyll fluorescence and GI was by repeated measures in time and for dry weight by Tukey's HSD.

\section{Results and Discussion}

Photosynthetically active radiation was $>900 \mu \mathrm{mol} \cdot \mathrm{m}^{-2} \cdot \mathrm{s}^{-1}$ for most of the days leaf gas exchange was measured (Fig. 1A). No information was found regarding photosynthetic light saturation for willows or virginia sweetspire, although for many full sun $\mathrm{C}_{3}$ plants it is between 800 to $1000 \mu \mathrm{mol} \mathrm{m}{ }^{-2} \cdot \mathrm{s}^{-1}$ (Crane et al., 1983; 

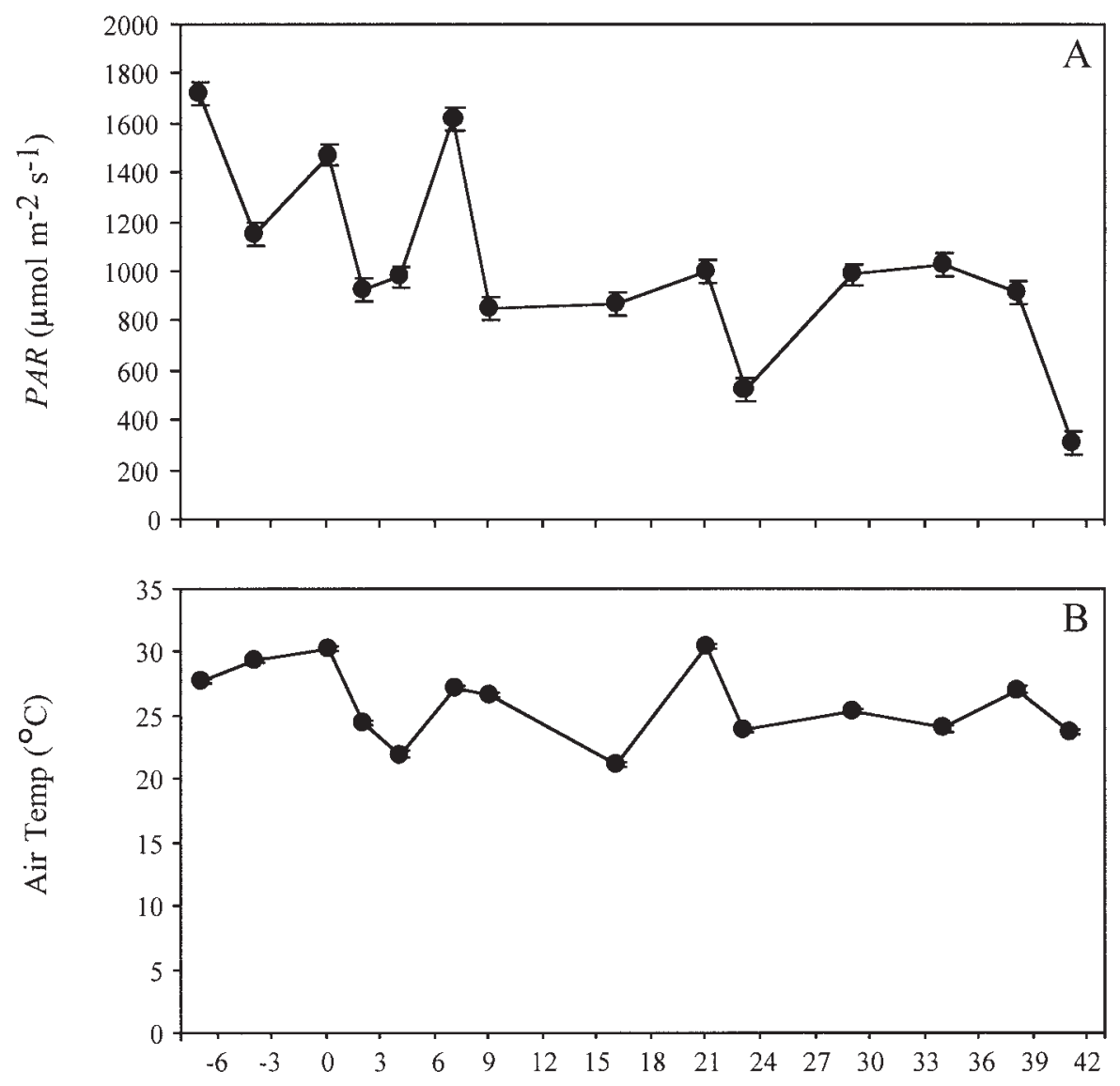

Treatment Days

Fig. 1. Photosynthetically active radiation $(P A R)(\mathbf{A})$ and air temperature $($ B $)( \pm$ sd $)$ during $\mathrm{CO}_{2}$ assimilation measurements before, during (day 0 of treatment was 18 July 2000) and after $9 \mathrm{~d}$ of exposure to $4 \mathrm{mg} \cdot \mathrm{L}^{-1}$ isoxaben and oryzalin. Before and after treatment with herbicides water, isoxaben and oryzalin-treated plants were grown under saturated water conditions and control was watered to runoff through drainage holes daily. During herbicide treatment, water and herbicides were replaced every second day with fresh water or herbicide suspensions and the control was watered to runoff through drainage holes daily.

Kaufmann, 1982; Sams and Flore, 1982). Air temperature was between 20 to $30{ }^{\circ} \mathrm{C}$ on almost all days during measurement of leaf gas exchange (Fig. 1B). The optimum rate of photosynthesis for most $\mathrm{C}_{3}$ plants occurs at temperatures between 20 to $30{ }^{\circ} \mathrm{C}$ (Crane et al., 1983; Farquhar and Sharkey, 1982; Sams and Flore, 1982; Sharkey, 1985).

There were few differences in A during the treatment period for virginia sweetspire (Table 1). However, following release from treatments there was an initial increase in A for the herbicide treated virginia sweetspire followed by a return to control levels for oryzalin-treated plants. Isoxaben-treated plants had lower A than all other treatments following release from treatments through termination of the experiment except for day 29. There were few differences in A for white willow between the control and herbicide treatments, although the water treatment was higher than the control on 4 of the 14 measurement days (Table 1). Initially, A of the water-treated black pussywillow was lower than the control for a few measurements but following day 9, there was only one difference in A (Table 1). During herbicide treatment, A was lower for the oryzalin-treated black pussywillows than control for two of the four measurements but only lower for
1 subsequent measurement. Following release from herbicide treatments, A was lower for isoxaben than control only twice and once for oryzalin-treated black pussywillows. Transpiration and stomatal conductance followed the same trends for A (data not shown).

Photosystem II efficiency (Fv/Fm) was reduced up to $50 \%$ for isoxaben-treated virginia sweetspire compared to other treatments from the last day of herbicide treatment throughout the recovery period except on day 13 (Table 2). There were few and inconsistent differences in $\mathrm{Fv} / \mathrm{Fm}$ among treatments for white willow (Table 2). There were no differences in $\mathrm{Fv} / \mathrm{Fm}$ before or during herbicide treatments for black pussywillow (Table 2). However, there was a reduction in $\mathrm{Fv} / \mathrm{Fm}$ from day 28 to 38 for isoxaben-treated black pussywillow compared to other treatments except the water treatment on day 28.

Reductions in Fv/Fm occurred before the reductions in A for isoxaben-treated plants. Chlorophyll fluorescence is not considered especially sensitive to water stress and usually is affected only after severe water stress (Fernandez et al., 1997; Karukstis, 1991; Krause and Weiss, 1984). Isoxaben is translocated quickly to leaves (Cabanne et al., 1987). The mode of action for isoxaben is to inhibit glucose incorporation into acid insoluble cell wall materials (Heim et al., 1990) In a previous study, early reductions in chlorophyll fluorescence for Canna $\times$ generalis and A for isoxaben treatments indicated an effect of the herbicide on photosynthesis rather than changes in water relations caused by damage to the root system (Fernandez et al., 1999). Results from this study demonstrate an effect of isoxaben on photosystem II and not an effect of water stress since differences in Fv/Fm were rare between water, oryzalin and control for all taxa.

Dinitroaniline herbicides, such as oryzalin, reduced $\mathrm{A}$ (Bhandary et al., 1997b) and inhibited photophosphorylation (Moreland et al., 1972a, 1972b). Twelve dinitroaniline herbicides were used in studies by Moreland (1972a, 1972b) and oryzalin caused the greatest reduction of A. Inhibition of photophosphorylation results in further reduction of $\mathrm{A}$ by reducing ATP availability. In a study to simulate contaminated irrigation water, A was reduced at 2 and 4 weeks when plants were irrigated over the canopy daily for 6 weeks with water containing $1 \mathrm{mg} \cdot \mathrm{L}^{-1}$ oryzalin (Bhandary et al., 1997b). However, dinitroanilines are not readily translocated in plants (Probst et al., 1975) and herbicides did not contact the foliage in this study. Reductions in A for oryzalin-treated plants were rare and occurred much later than for isoxaben-treated plants which could be due either to changes in water relations caused by root damage or accumulation of damaging levels of oryzalin. Although oryzalin is not translocated readily, when using contaminated reclaimed water for overhead irrigation, there is the possibility of absorption by leaves.

Growth was strongly reduced by isoxaben and moderately reduced by oryzalin. Growth index of isoxaben-treated virginia sweetspire decreased by termination of the experiment while GI 
Table 1. $\mathrm{CO}_{2}$ assimilation $\left(\mathrm{mmol} \cdot \mathrm{m}^{-2} \cdot \mathrm{s}^{-1}\right.$ ) for virginia sweetspire, white willow and black pussy willow before, during (day 0 of treatment was 18 July 2000), and after $9 \mathrm{~d}$ of exposure to $4 \mathrm{mg} \cdot \mathrm{L}^{-1}$ isoxaben and oryzalin. Before and after treatment with herbicides, water-, isoxaben-, and oryzalin-treated plants were grown under saturated water conditions and the control was watered to runoff through drainage holes daily. During herbicide treatment, water and herbicides were replaced every second day with fresh water or herbicide suspensions and control was watered to runoff through drainage holes daily.

\begin{tabular}{|c|c|c|c|c|c|c|c|c|c|c|c|c|c|c|}
\hline Treatment & \multicolumn{14}{|c|}{ Treatment days } \\
\hline \multicolumn{15}{|c|}{ Virginia sweetspire } \\
\hline Water & $7.1 \mathrm{a}$ & $4.1 \mathrm{a}$ & $7.8 \mathrm{a}$ & $4.7 \mathrm{a}$ & $5.8 \mathrm{a}$ & $7.8 \mathrm{ab}$ & $6.2 \mathrm{a}$ & $6.3 \mathrm{~b}$ & $6.1 \mathrm{a}$ & $4.8 \mathrm{a}$ & $8.0 \mathrm{a}$ & $6.5 \mathrm{a}$ & $7.6 \mathrm{a}$ & $4.2 \mathrm{a}$ \\
\hline Isoxaben & $7.1 \mathrm{a}$ & $4.1 \mathrm{a}$ & $9.1 \mathrm{a}$ & $5.7 \mathrm{a}$ & $6.5 \mathrm{a}$ & $11.3 \mathrm{a}$ & $4.0 \mathrm{a}$ & $10.9 \mathrm{a}$ & $1.6 \mathrm{~b}$ & $2.0 \mathrm{~b}$ & $10.3 \mathrm{a}$ & $1.4 \mathrm{~b}$ & $0.4 \mathrm{~b}$ & $1.4 \mathrm{a}$ \\
\hline Oryzalin & $10.4 \mathrm{a}$ & $5.3 \mathrm{a}$ & $7.5 \mathrm{a}$ & $6.4 \mathrm{a}$ & $6.9 \mathrm{a}$ & $8.5 \mathrm{ab}$ & $6.6 \mathrm{a}$ & $10.6 \mathrm{ab}$ & $7.9 \mathrm{a}$ & $5.0 \mathrm{a}$ & $6.9 \mathrm{a}$ & $5.0 \mathrm{a}$ & $6.4 \mathrm{a}$ & $3.7 \mathrm{a}$ \\
\hline Water & $16.4 \mathrm{a}$ & $10.8 \mathrm{a}$ & $13.8 \mathrm{a}$ & $18.9 \mathrm{a}$ & $19.8 \mathrm{a}$ & $14.9 \mathrm{a}$ & $17.9 \mathrm{a}$ & $11.0 \mathrm{a}$ & $13.7 \mathrm{a}$ & $9.3 \mathrm{a}$ & $7.1 \mathrm{a}$ & $9.7 \mathrm{a}$ & $13.7 \mathrm{a}$ & $5.9 \mathrm{a}$ \\
\hline Isoxaben & $14.4 \mathrm{~b}$ & $10.2 \mathrm{a}$ & $7.5 \mathrm{~b}$ & $19.6 \mathrm{a}$ & $20.7 \mathrm{a}$ & $6.3 \mathrm{~b}$ & $17.2 \mathrm{a}$ & $8.2 \mathrm{a}$ & $6.2 \mathrm{a}$ & $5.3 \mathrm{a}$ & $7.5 \mathrm{a}$ & $9.5 \mathrm{a}$ & $11.1 \mathrm{ab}$ & $6.8 \mathrm{a}$ \\
\hline Oryzalin & $13.9 \mathrm{~b}$ & $10.4 \mathrm{a}$ & $7.6 \mathrm{~b}$ & $16.3 \mathrm{a}$ & $18.6 \mathrm{ab}$ & $4.9 \mathrm{~b}$ & $13.8 \mathrm{a}$ & $11.9 \mathrm{a}$ & $8.5 \mathrm{a}$ & $5.6 \mathrm{a}$ & $5.7 \mathrm{a}$ & $10.0 \mathrm{a}$ & $11.1 \mathrm{ab}$ & $5.4 \mathrm{a}$ \\
\hline \multicolumn{15}{|c|}{ Black pussy willow } \\
\hline Control & $17.7 \mathrm{a}$ & $17.1 \mathrm{a}$ & $5.9 \mathrm{a}$ & $24.3 \mathrm{a}$ & $21.1 \mathrm{a}$ & $5.0 \mathrm{~b}$ & $22.4 \mathrm{a}$ & $12.0 \mathrm{a}$ & $16.9 \mathrm{ab}$ & $11.9 \mathrm{a}$ & $7.0 \mathrm{a}$ & $13.4 \mathrm{ab}$ & $10.0 \mathrm{~b}$ & $8.4 \mathrm{a}$ \\
\hline
\end{tabular}

${ }_{\mathrm{z}}^{\mathrm{z}}$ Means within columns and taxa followed by different letters are significantly different at $P \leq 0.05$ by repeated measures in time analysis.

Table 2. Photosystem II efficiency (Fv/Fm) for virginia sweetspire, white willow and black pussy willow before, during (day 0 of treatment was 18 July 2000), and after $9 \mathrm{~d}$ of exposure to $4 \mathrm{mg} \cdot \mathrm{L}^{-1}$ isoxaben and oryzalin. Before and after treatment with herbicides, water-, isoxaben-, and oryzalin-treated plants were grown under saturated water conditions and the control was watered to runoff through drainage holes daily. During herbicide treatment, water and herbicides were replaced every second day with fresh water or herbicide suspensions and control was watered to runoff through drainage holes daily.

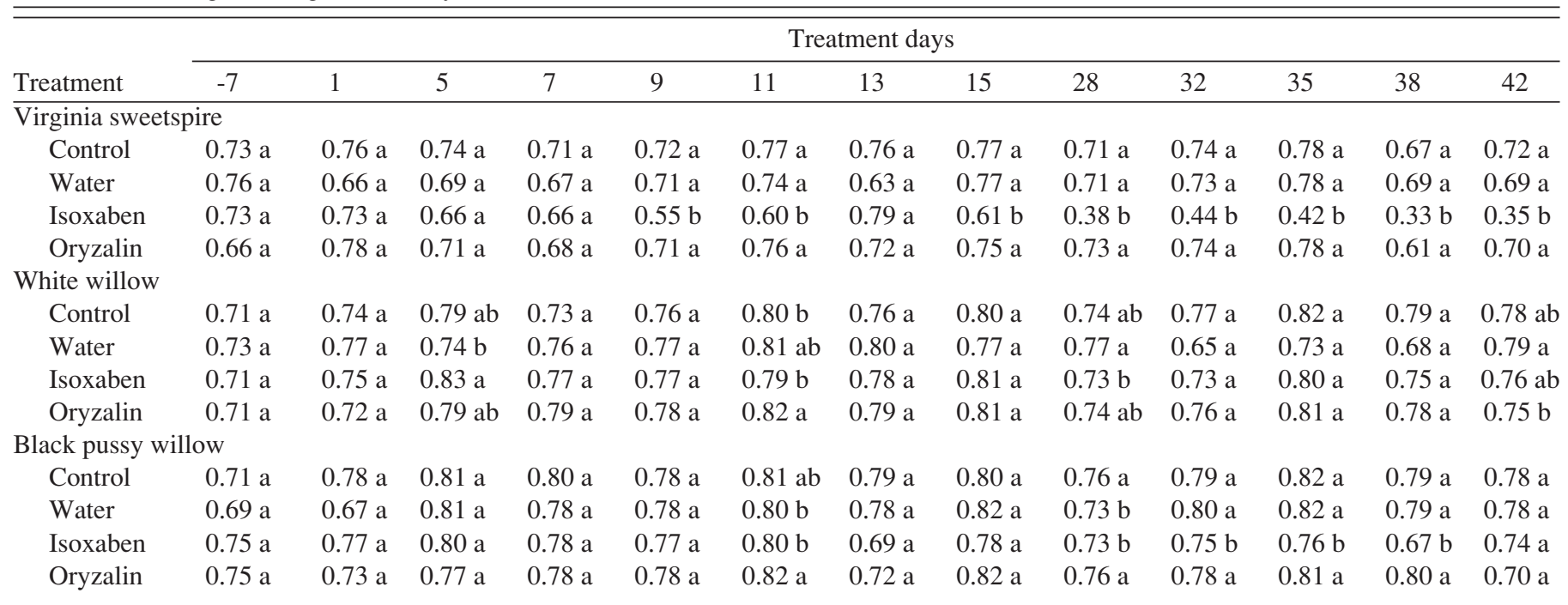

${ }^{\mathrm{z}}$ Means within columns and taxa followed by different letters are significantly different at $P \leq 0.05$ by repeated measures in time analysis.

was similar or higher for oryzalin and water treatments than control (Fig. 2A). Growth index of white willow was lower for both herbicides on day 9 compared to control, while only GI for the isoxaben treatment remained lower by the end of the experiment (Fig. 2B). A pattern similar to that for white willow was seen for black pussywillow except both herbicides resulted in large reductions in GI by termination of the experiment (Fig. 2C).

Leaf dry weight was lower for oryzalin-treated black pussywillow versus control by the end of treatment although there were no other differences in dry weight for other treatments or for white willow (Table 3). At termination of the experiment, shoot dry weight was $22 \%$ of control for isoxaben-treated virginia sweetspire but no other treatments differed for virginia sweetspire (Table 4). Root dry weight of virginia sweetspire was $42 \%, 4 \%$, and $32 \%$ of the control for water, isoxaben and oryzalin treatments, respectively. The root to shoot ratio of virginia sweetspire was much lower for water and herbicide treatments versus control. Total dry weight of virginia sweetspire was $57 \%, 8 \%$, and $48 \%$ of the control for water, isoxaben and oryzalin, respectively, with the majority of dry weight reduction being due to large differences in root dry weight, except for isoxaben where both shoot and root dry weights were lower than control. Shoot dry weight of white willow was lower for both herbicide treatments than for the control and water treatment (Table 4). There was no 
difference in root dry weight of white willow between control and water but both herbicide treatments were lower than control and the isoxaben treatment was lower than water as well. The root to shoot ratio of white willow was reduced for isoxaben versus control but no other treatments were different. Total dry weight of white willow was not different between control and water but was lower for both herbicides compared to control and isoxaben also was lower than water. There were no differences in root, shoot, or total dry weight of black pussywillow between control and water treatments. However, both herbicide treatments had lower root, shoot and total dry weights relative to the control and

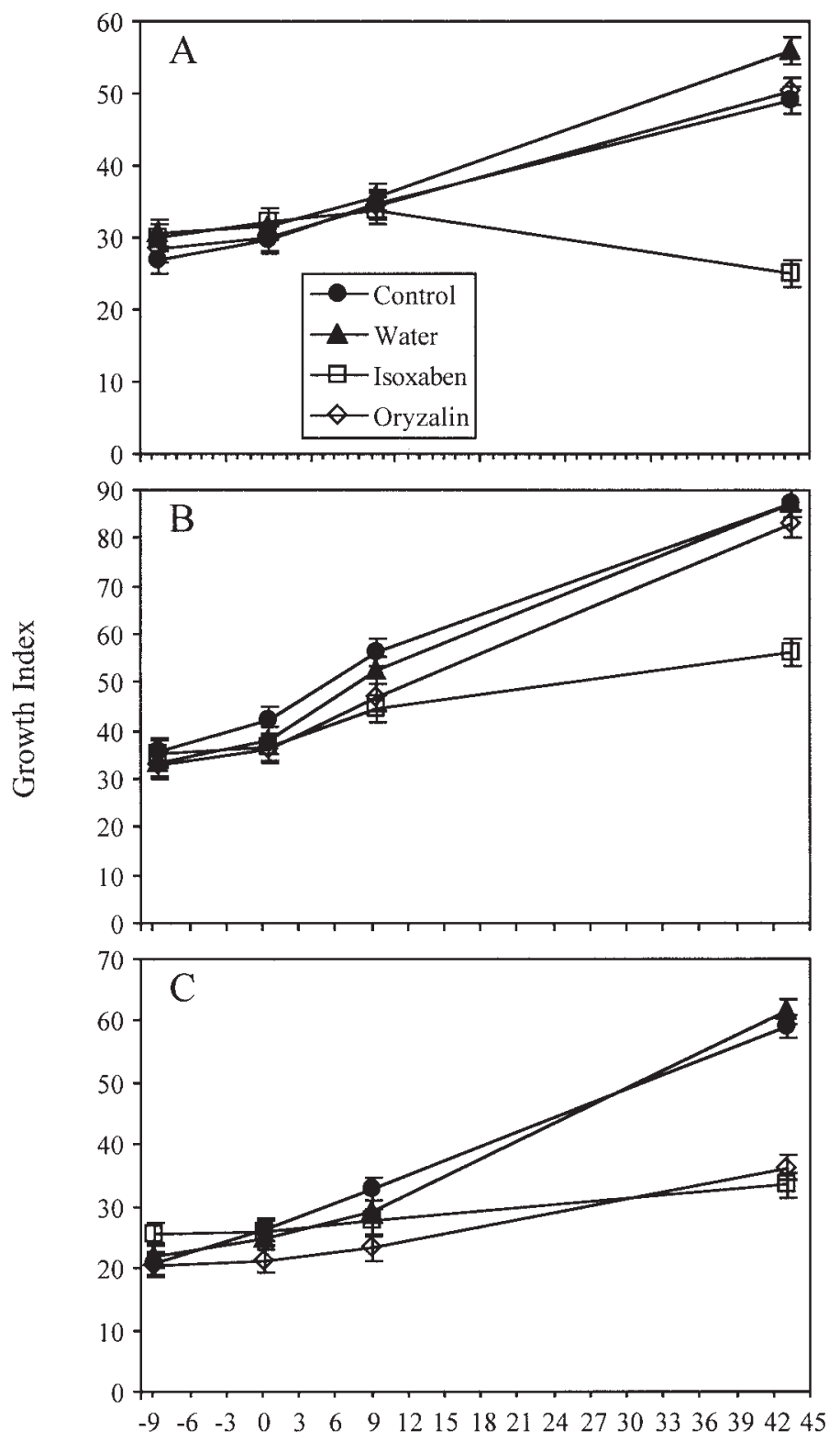

Treatment Days

Fig. 2 Growth index ( \pm sd) [(height + width)/2] before, during (day 0 of treatment was 18 July 2000) and after $9 \mathrm{~d}$ of exposure to $4 \mathrm{mg} \cdot \mathrm{L}^{-1}$ isoxaben and oryzalin for virginia sweetspire (A), white willow (B), and black pussywillow (C). Before and after treatment with herbicides water, isoxaben and oryzalin-treated plants were grown under saturated water conditions and control was watered to runoff through drainage holes daily. During herbicide treatment, water and herbicides were replaced every second day with fresh water or herbicide suspensions and the control was watered to runoff through drainage holes daily. water treatments (Table 4). The root to shoot ratio of black pussywillow was lower for all treatments versus control.

Anoxic conditions can reduce growth of plants unable to oxygenate the rhizosphere (Smucker, 1984). However, the frequent changes in treatment solutions should not have resulted in anoxia. For virginia sweetspire, shoot dry weight and GI were not affected by the water treatment and only root dry weight was reduced compared to control. The root to shoot ratio was de-

Table 3. Dry weight after $9 \mathrm{~d}$ of exposure to $4 \mathrm{mg} \cdot \mathrm{L}^{-1}$ isoxaben and oryzalin for virginia sweetspire, white willow and black pussy willow. Seven days before treatment with herbicides water, isoxaben and oryzalin treated plants were grown under saturated water conditions and the control was watered to runoff through drainage holes daily. During herbicide treatment, water and herbicides were replaced every second day with fresh water or herbicide suspensions and the control was watered to runoff through drainage holes daily.

\begin{tabular}{llllr}
\hline \hline & \multicolumn{4}{c}{ Dry wt (g) } \\
\cline { 2 - 5 } Treatment & Shoot & Root & Leaf & Total \\
\hline White willow & $5 \mathrm{a}$ & $70 \mathrm{a}$ & $3 \mathrm{a}$ & $79 \mathrm{a}$ \\
$\quad$ Control & $4 \mathrm{a}$ & $99 \mathrm{a}$ & $2 \mathrm{a}$ & $105 \mathrm{a}$ \\
Water & $5 \mathrm{a}$ & $50 \mathrm{a}$ & $2 \mathrm{a}$ & $74 \mathrm{a}$ \\
Isoxaben & $4 \mathrm{a}$ & $68 \mathrm{a}$ & $2 \mathrm{a}$ & $58 \mathrm{a}$ \\
Oryzalin & & & & \\
Black pussy willow & $4 \mathrm{a}$ & $87 \mathrm{a}$ & $3 \mathrm{ab}$ & $94 \mathrm{a}$ \\
Control & $5 \mathrm{a}$ & $75 \mathrm{a}$ & $2 \mathrm{bc}$ & $83 \mathrm{a}$ \\
Water & $6 \mathrm{a}$ & $97 \mathrm{a}$ & $3 \mathrm{a}$ & $106 \mathrm{a}$ \\
Isoxaben & $4 \mathrm{a}$ & $87 \mathrm{a}$ & $2 \mathrm{c}$ & $93 \mathrm{a}$ \\
Oryzalin & &
\end{tabular}

${ }^{\overline{\mathrm{z}} \text { Means within columns and taxa followed by different letters are }}$ significantly different at $P \leq 0.05$ by Tukey's HSD.

Table 4. Final dry weight for virginia sweetspire, white willow and black pussy willow exposed to $9 \mathrm{~d}$ of saturated water or $4 \mathrm{mg} \cdot \mathrm{L}^{-1}$ isoxaben or oryzalin and $35 \mathrm{~d}$ of recovery. Seven days before treatment with herbicides water-, isoxaben-, and oryzalin-treated plants were grown under saturated water conditions and the control was watered to runoff through drainage holes daily. During herbicide (day 0 of treatment was 18 July 2000), water and herbicides were replaced every second day with fresh water or herbicide suspensions and the control was watered to runoff through drainage holes daily.

\begin{tabular}{lcccc}
\hline \hline & $\begin{array}{c}\text { Shoot } \\
\text { dry wt } \\
(\mathrm{g})\end{array}$ & $\begin{array}{c}\text { Root } \\
\text { dry wt } \\
(\mathrm{g})\end{array}$ & $\begin{array}{c}\text { Root to } \\
\text { shoot } \\
\text { ratio }\end{array}$ & $\begin{array}{c}\text { Total } \\
\text { dry wt } \\
(\mathrm{g})\end{array}$ \\
Treatment & & & & \\
Virginia Sweetspire & & & & \\
Control & $37 \mathrm{a}$ & $134 \mathrm{a}$ & $3.6 \mathrm{a}$ & $172 \mathrm{a}$ \\
Water & $41 \mathrm{a}$ & $56 \mathrm{~b}$ & $1.3 \mathrm{~b}$ & $98 \mathrm{~b}$ \\
Isoxaben & $8 \mathrm{~b}$ & $6 \mathrm{c}$ & $1.0 \mathrm{~b}$ & $14 \mathrm{c}$ \\
Oryzalin & $39 \mathrm{a}$ & $43 \mathrm{bc}$ & $0.8 \mathrm{~b}$ & $82 \mathrm{~b}$ \\
White Willow & & & & \\
Control & $26 \mathrm{a}$ & $47 \mathrm{a}$ & $1.7 \mathrm{a}$ & $73 \mathrm{a}$ \\
Water & $26 \mathrm{a}$ & $35 \mathrm{ab}$ & $1.2 \mathrm{ab}$ & $62 \mathrm{ab}$ \\
Isoxaben & $11 \mathrm{~b}$ & $9 \mathrm{c}$ & $0.8 \mathrm{~b}$ & $20 \mathrm{c}$ \\
Oryzalin & $17 \mathrm{~b}$ & $19 \mathrm{bc}$ & $1.0 \mathrm{ab}$ & $36 \mathrm{bc}$ \\
Black Pussy Willow & & & & \\
Control & $33 \mathrm{a}$ & $45 \mathrm{a}$ & $1.5 \mathrm{a}$ & $74 \mathrm{a}$ \\
Water & $29 \mathrm{a}$ & $34 \mathrm{a}$ & $1.0 \mathrm{~b}$ & $67 \mathrm{a}$ \\
Isoxaben & $13 \mathrm{~b}$ & $7 \mathrm{~b}$ & $0.6 \mathrm{~b}$ & $21 \mathrm{~b}$ \\
Oryzalin & $16 \mathrm{~b}$ & $10 \mathrm{~b}$ & $0.7 \mathrm{~b}$ & $26 \mathrm{~b}$
\end{tabular}

${ }^{\mathrm{z}}$ Means within columns and taxa followed by different letters are significantly different at $P \leq 0.05$ by Tukey's HSD. 
creased for most treatments and higher available substrate moisture content in the water treatment may have resulted in a shift of carbohydrates from the roots to the shoots as has been noted for other plants (Smucker, 1984). A smaller root system may be capable of supplying plant water requirements as substrate moisture content increases (Cripps, 1971; Maggs, 1961). Water alone did not result in reduced total dry weight or GI for the willows, however, the herbicide treatments resulted in reduced total, shoot and root dry weight and lower GI. There was no difference in shoot dry weight between control, water and oryzalin treatments for virginia sweetspire although isoxaben was lower overall. Oryzalin damage symptoms, shortened and thickened roots, were observed on roots of all oryzalin-treated plants. Oryzalin affects mitosis by inhibiting microtubule formation (Strachan and Hess, 1983).

Isoxaben had the greatest effect compared to other treatments with large reductions in GI and dry weight for all taxa and consistent decreases in $\mathrm{Fv} / \mathrm{Fm}$ and frequent decreases in $\mathrm{A}$ for virginia sweetspire and black pussywillow. The effects of oryzalin on plant performance were similar to that of water except for black pussywillow where growth was reduced similarly to isoxaben. The major reduction in dry weight for water and oryzalin-treated virginia sweetspire and white willow were due to decreased root dry weight which may have been due to high water availability rather than herbicide damage. However, large reductions were found for both shoot and root dry weight for all isoxaben-treated plants and oryzalin-treated black pussywillow.

Isoxaben was more damaging than oryzalin to all taxa in this study. Virginia sweetspire and white willow were tolerant of high oryzalin concentrations while black pussywillow responded poorly to both herbicides. Exposure of semiaquatic herbaceous perennials to similar levels and durations of isoxaben and oryzalin resulted in more rapid, frequent and larger reductions in $\mathrm{A}$, transpiration and chlorophyll fluorescence, especially for isoxaben (Fernandez et al., 1999), than was found in this study. The use of virginia sweetspire and white willow for phytoremediation of water contaminated with oryzalin and probably other dinitroaniline herbicides appears to be promising based on tolerance. None of the woody perennials in this study or the herbaceous perennials in a similar study (Fernandez et al., 1999) showed promise for phytoremediation of isoxaben at the levels used in these studies.

\section{Literature Cited}

Anonymous. 1987. EL-107 An experimental herbicide for preemergent control of broadleaf weeds. Lilly Res. Lab., Indianapolis, Ind.

Anonymous. 1993. U.S. Environmental Protection Agency integrated risk information system-Oryzalin. http://www.epa.gov/iris/subst/ 0083.htm.

Anonymous. 1995. U.S. National Library of Medicine. Hazardous Substances Databank. Bethesda, Md., 10-9.

Anonymous. 1996. Pesticide information profiles: Oryzalin. http:// ace.orst.edu/cgi-bin/mfs/01/pips/oryzalin.htm?8.

Anonymous. 2000. Gallery 75DF herbicide material safety data sheet. Dow AgroSciences LLC, Indianapolis, Ind.

Anonymous. 2001a. U.S. Environmental Protection Agency integrated risk information system-Isoxaben. http://www.epa.gov/iris/subst/ 0339.htm.

Anonymous. 2001b. California code of regulations (Title 3. Food and Agriculture) Updated: 01/14/01. Division 6. Pesticides and Pest Control Operations. Chapter. 1 Pesticide Regulatory Program. http:// www.cdpr.ca.gov/docs/inhouse/calcode/chapter_htm.

Anonymous. 2002. Surflan A.S. herbicide-ornamentals material safety data sheet. Dow AgroSciences LLC, Indianapolis, Ind.
Bhandary, R., T. Whitwell, and J. Briggs. 1997a. Growth of containerized landscape plants is influenced by herbicides residues in irrigation water. Weed Technol. 11:793-797.

Bhandary, R., T. Whitwell, J. Briggs, and R.T. Fernandez. 1997b. Influence of Surflan (oryzalin) concentrations in irrigation water on growth and physiological processes of Gardenia jasminoides radicans and Pennisetum rupelli. J. Environ. Hort. 169-172.

Bilderback, T.E., M.A. Powell, T.M. Losordo, S.W. Broome, and S.H. Kay. 1993. An aquatic plant production and nutrient mitigation system. S. Nurserymen's Assn. Res. Conf. 38th Annu. Rpt. p. 422-426.

Briggs, J.A. 1996. Characterization and remediation of pesticides transported in runoff water from a containerized plant nursery. MS thesis, Clemson Univ., Clemson, S.C.

Briggs, J.A., M.B. Riley, and T. Whitwell. 1998. Characterization and remediation of pesticides in runoff water from containerized plant production. J. Environ. Qual. 27:814-820.

Cabanne, R., A. Lefebvre, and R. Scalla. 1987. Behaviour of the herbicide EL-107 in wheat and rape grown under controlled conditions. Weed Res. 27:135-142.

Camper, N.D., T. Whitwell, R.J. Keese, and M.B. Riley. 1994. Herbicide levels in nursery containment pond water and sediments. J. Environ. Hort. 12:8-12.

Chaubey, I., D.R. Edwards, T.C. Daniel, P.A. Moore, Jr., and D.J. Nichols. 1994. Effectiveness of vegetative filter strips in retaining surface-applied swine manure constituents. Trans. Amer. Soc. Agr. Eng. 37:845-850.

Crane, Jr., J.L., D.I. Dickmann, and J.A. Flore. 1983. Photosynthesis and transpiration by young Larix kaempferi trees: $\mathrm{C}_{3}$ responses to light and temperature. Physiol. Plant. 59:635-640.

Cripps, J.E.L. 1971. The influence of soil moisture on apple root growth and root:shoot ratios. J. Hort. Sci. 46:121-130.

Dillaha, T.A., R.B. Reneau, S. Mostaghimi, and D. Lee. 1989. Vegetative filter strips for agricultural nonpoint source pollution control. Trans. Amer. Soc. Agr. Eng. 32:513-519.

Farquhar, G.D. and T.D. Sharkey. 1982. Stomatal conductance and photosynthesis. Annu. Rev. Plant Physiol. 33:317-345.

Fernandez, R.T., R.L. Perry, and J.A. Flore. 1997. Drought response of young apple trees on three rootstocks. II. Gas exchange, chlorophyll fluorescence, water relations, and leaf abscisic acid. J. Amer. Soc. Hort. Sci. 122:841-848.

Fernandez, R.T., T. Whitwell, M.B. Riley, and C.R. Bernard. 1999. Evaluating semiaquatic herbaceous perennials for use in herbicide phytoremediation. J. Amer. Soc. Hort. Sci. 124:539-544.

Gilliam, C.H., D.C. Fare, and A. Beasley. 1992. Nontarget herbicide losses from application of granular ronstar to container nurseries. J. Environ. Hort. 10:175-176.

Heim, D.R., J.R. Skomp, E.E. Tschabold, and I.M. Larrinua. 1990. Isoxaben inhibits the synthesis of acid insoluble cell wall materials in Arabidopsis thaliana. Plant Physiol. 93:695-700.

Karukstis, K.K. 1991. Chlorophyll fluorescence as a physiological probe of the photosynthetic apparatus, p. 769-795. In: H. Sheer (ed.). Chlorophylls. CRC Press, Boca Raton, Fla.

Kaufmann, M.R. 1982. Leaf conductance as a function of photosynthetic photon flux density and absolute humidity difference from leaf to air. Plant Physiol. 69:1018-1022.

Keese, R.J., N.D. Camper, T. Whitwell, M.B. Riley, and P.C. Wilson. 1994. Herbicide runoff from ornamental container nurseries. J. Environ. Qual. 23:320-324.

Krause, G.H. and E. Weiss. 1984. Chlorophyll fluorescence as a tool in plant physiology. II. Interpretation of fluorescence signals. Photosynthesis Res. 5:139-157.

Maggs, D.H. 1961. Changes in the amount and distribution of increment induced by contrasting watering, nitrogen and environmental regimes. Ann. Bot. 25:353-361.

Moreland, D.E., F.S. Farmer, and G.G. Hussey. 1972a. Inhibition of photosynthesis and respiration by substituted 2,6-dinitroaniline herbicides. I. Effects on chloroplast and mitochondrial activities. Pest. Biochem. Physiol. 2:342-353 
Moreland, D.E., F.S. Farmer, and G.G. Hussey. 1972b. Inhibition of photosynthesis and respiration by substituted 2,6-dinitroaniline herbicides. II. Effects on responses in excised plant tissues and treated seedlings. Pest. Biochem. Physiol. 2:342-353

Neal, J.C. and A.F. Senesac. 1990. Summer annual and winter annual weed control in field soil and soilless media with Gallery (isoxaben). J. Environ. Hort. 8:124-127.

Pritchard, T.W., J.G. Lee, and B.A. Engel. 1993. Reducing agricultural sediment: An economic analysis of filter strips versus micro-targeting. Water Sci. Technol. 28:561-568.

Probst, G.W., T. Golab, and W.L. Wright. 1975. Dinitroanilines, p. 453 500. In: P.C. Kearney and D.D. Kaufman (eds.). Herbicides: Chemistry, degradation, and mode of action. vol. I. Marcel Dekker, New York.

Riley, M.B., R.J. Keese, N.D. Camper, T. Whitwell, and P.C. Wilson. 1994. Pendimethalin and oxyfluorfen residues in pond water and sediment from container plant nurseries. Weed Technol. 8:299-303.

Sams, C.E. and J.A. Flore. 1982. The influence of age, position, and environmental variables on net photosynthetic rate of sour cherry leaves. J. Amer. Soc. Hort. Sci. 107:339-344.

Sharkey, T.D. 1985. Photosynthesis in intact leaves of $\mathrm{C}_{3}$ plants: Physics, physiology, and rate limitations, p. 53-105. In: The botanical review. V.51. The New York Botanical Garden, New York.

Shimp, J.F., J.C. Tracy, L.C. Davis, E. Lee, W. Huang, and L.E.
Erickson. 1993. Beneficial effects of plants in the remediation of soil and groundwater contaminated with organic materials. Crit. Rev. Environ. Sci. Technol. 23:41-77.

Skimina, C.A. 1992. Recycling water, nutrients, and waste in the nursery industry. HortScience 27:968-971.

Skroch, W.A., C.J. Catanzaro, A.A. DeHertogh, and L.B. Gallitano. 1994. Preemergence herbicide evaluations on selected spring and summer flowering bulbs and perennials. J. Environ. Hort. 12:80-82.

Smucker, A.J.M. 1984. Carbon utilization and losses by plant root systems, p. 27-46. In: S.A. Barber and D.R. Bouldin (eds.). Roots, nutrient and water influx, and plant growth. Soil Sci. Soc. Amer., Madison, Wis.

Strachan, S.D. and F.D. Hess. 1983. The biochemical mechanism of action of the dinitroaniline herbicide oryzalin. Pesticide Biochem. Physiol. 20:141-150.

Thut, R.N. 1990. Utilization of artificial marshes for treatment of pulp mill effluent. Tech. Assn. Pulp Paper Ind. J. 73:93-96.

Wilson, C., T. Whitwell, and M.B. Riley. 1996. Detection and dissipation of isoxaben and trifluralin in containerized plant nursery runoff water. Weed Sci. 44:683-688.

Wolverton, B.C., R.C. McDonald, and W.R. Duffer. 1983. Microorganisms and higher plants for waste water treatment. J. Environ. Qual. $12: 236-242$. 